\title{
Genital human papillomavirus infection among patients attending an STD clinic
}

\author{
A Strand, E Rylander, M Evander, G Wadell
}

\begin{abstract}
Objectives-To determine the prevalence of human papillomavirus (HPV) infection in patients, male and female, attending a clinic for sexually transmitted diseases (STDs).

Design-A randomly selected group of patients representative of the population studied and first-time visitors to the STD clinic, were asked to participate in the study. Samples from the skin and mucous membranes of the lower genital region were taken for cytological analysis by the polymerase chain reaction (PCR) method for HPV DNA. The patients then underwent colposcopy or peniscopy after acetic acid application.
\end{abstract}

Setting-Department of Dermatology and Venereology, University Hospital, Uppsala, Sweden.

Subjects-A total of 131 patients, 66 women and 65 men, attending the clinic for various reasons.

Results-At colposcopy / peniscopy, 18 patients (10 men and 8 women) had lesions typical of, and 24 (12 men and 12 women) suspicious of HPV infection. With the PCR technique HPV DNA was detected in $72 \%$ of the patients with typical lesions and in $54 \%$ of those with suspicious lesions.

Conclusion-Nearly one-third or $30.5 \%$ of these randomly selected patients in a Swedish STD clinic were infected by HPV. The diagnosis was made by clinical inspection and/or by HPV DNA analysis with PCR.

(Genitourin Med 1993;69:446-449)

Departments of Dermatology and Venereology A Strand

Gynaecology and Obstetrics, University Hospital, Uppsala, Sweden E Rylander

Department of Virology, University of Umeå, Sweden M Evander G Wadell

Address correspondence to: Dr Anders Strand, Department of Dermatology and Venereology,

University Hospital S-751 85 Uppsala, Sweden.

Accepted for publication 11 August 1993

\section{Introduction}

During the last decade the panorama of sexually transmitted diseases (STDs) has changed. Human papilloma virus (HPV) infection, which previously was not considered to be a major problem in relation to the gonorrhoea and chlamydia epidemics, now seems to have become the most common sexually transmitted disease in Sweden. As long as the virus cannot be totally eradicated, the only solution is to prevent further spread as much as possible by thorough examination of the patients attending clinics for STD, and counselling about the limited treatment possibilities and how to avoid getting infected.

The prevalence of HPV infection among patients consulting an STD clinic is today a matter of concern since published reports have shown great variability $(28-84 \%) .{ }^{12}$ As in these studies, we used polymerase chain reaction (PCR) analysis of cell samples for the detection of HPV DNA, which is a simple and non invasive technique convenient for everyday use. Replication of HPV takes place in the superficial layers of the keratinocytes, a fact which favours the possibility of detecting HPV DNA by cell sampling. ${ }^{3}$

This paper concerns the prevalence of HPV infection found in a mainly young population attending a Swedish STD clinic. The infection was diagnosed either in the traditional way, that is by inspection after acetic acid application with magnification, in this study with the use of colposcopy, or by detection of HPV DNA using the PCR technique.

\section{Material and methods}

The STD clinic studied covers a population of about 175000 people of whom 25000 are university students. These students constitute a risk group for acquisition of STDs. ${ }^{45}$

\section{Patients}

People generally consult the STD clinic either because of symptoms or because of a wish to be screened for the presence of any STD. The study patients (131) was selected randomly during the one year, February 1991 to January 1992, from the study poulation $(4,579)$. Most patients in the area are referred to the STD clinic for screening and treatment for STDs and very few of these patients are seen by general practicians or private doctors. We therefore consider our sample to be representative of the population studied.

One hundred and thirty-one first-time visitors ( 66 women and 65 men) were randomly selected and included in the study. Their ages ranged from 17-53 years (median 25). A detailed medical history regarding previous STDs and other illnesses was taken. Information about use of condoms, number of sexual partners during the last year and duration of exposure time to the current sexual partner was also obtained (table 1).

The patients were informed of the purpose of the study (informed consent) and the participation was voluntary. The study was approved by the local ethic committee.

\section{Methods}

Samples from the mucous membranes and the skin for cytological analysis were obtained with the use of a Cytobrush $($ (Medscand AB, Malmö, Sweden).

In women, cell scrapings were obtained from the outer genitals, vulva, introitus, perineum and the perianal area with one 
Table 1 Medical and behavioural history

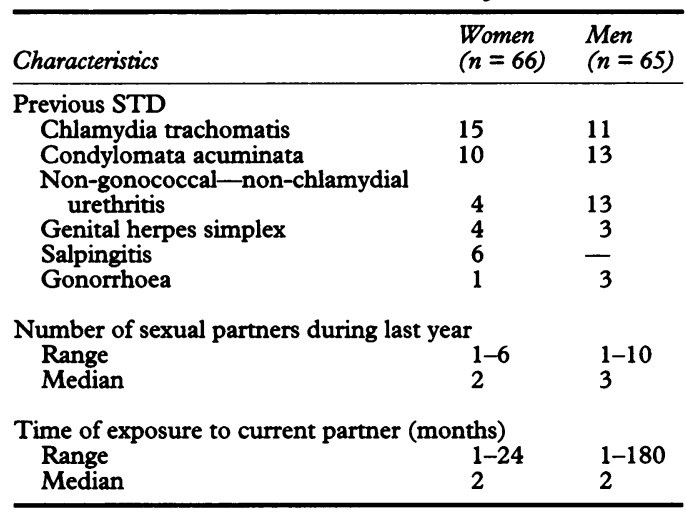

cytobrush and from the cervix uteri with another. The samples were individually placed in two different sterile pre-capped plastic tubes containing Tris-HCl, EDTA buffer saline. The skin and the mucous membranes were then examined with a colposcope (OMPI Zeiss) after application of $5 \%$ acetic acid. Women with anal and/or perianal lesions were examined with a proctoscope.

In men sampling was performed from the distal part of the urethra $(2-3 \mathrm{~cm})$ with a plastic probe, of the same type used for collecting samples for light microscopy for diagnosis of urethritis. From the glans penis, sulcus, preputium and the penile shaft, cells were collected with a cytobrush. These two samples were placed in one plastic tube containing Tris- $\mathrm{HCl}$, EDTA buffer saline. Acetic acid, $5 \%$, was applied and three to five minutes later colposcopy (peniscopy) was carried out. The distal part of the urethra was visualized with a nasal speculum. If any anal and/or perianal lesions were detected, proctoscopic examination was also performed.

Screening by cultures for Chlamydia trachomatis and microscopy for cervicitis and urethritis was carried out in all patients. Samples for gonorrhoea were obtained in 17 patients because of sexual contact from abroad. Immunofluorecence test from direct smears for herpes simplex virus antigen were performed if lesions suspected to be genital herpes were present.

\section{Detection of HPV DNA}

The collected cells were suspended in a plastic tube containing $1.5 \mathrm{ml}$ of STE $(100 \mathrm{mM}$ $\mathrm{NaCl}, 10 \mathrm{mM}$ Tris- $\mathrm{HCl}$, [pH 8,1] $\mathrm{mM}$ EDTA). The tubes were stored frozen until the analysis took place. The solution was then centrifuged to pellet the cells. The DNA was prepared as described previously. ${ }^{6}$ Amplification of HPV DNA was carried out by two general primer pairs. The MY11-MY09 concensus primer pairs which spans nucleotides 6722 to 7170 in HPV type 6 and corresponding regions of the other genital $\mathrm{HPVs}^{7}$ was used in combination with the GP5-GP6 general primer pair, which spans nucleotides 6764-6902 in HPV 6 and the corresponding regions of other genital HPVs in a nested general primer two-step amplification of the HPV DNA (20 cycles MY11-MY09, 30 cycles GP5-GP6). ${ }^{8}$
All specimens were also amplified with the $\beta$-globin primers PC03 and PC04 to exclude false negative results. ${ }^{9}$ Samples that were negative for $\beta$-globin amplification were extracted with phenol and precipitated with ethanol, and a second $\beta$-globin PCR was performed. All $\beta$-globin-positive samples were amplified with the HPV primers.

All PCRs were performed so that every fifth sample was a negative control. All such controls were negative. To minimize the risk of contamination, strict precautions were taken during sample collection, preparation of DNA and PCR. Detection and hybridisation were carried out as described earlier. ${ }^{10}$

\section{Results}

Of the 131 patients examined, 18 (10 men and 8 women) had acuminate or papulous condylomata and 24 (12 men and 12 women) had lesions suspicious of HPV infection (acetowhite lesions), as observed at colposcopy/peniscopy. Of the patients with exophytic condylomata, $72 \%$ were positive with the PCR technique, and of those with lesions suspicious of HPV infection $54 \%$ were positive with PCR. Of the 89 patients without any clinical signs of HPV, nine $(10 \%)$ were HPV positive with use of the PCR technique.

Altogether 35 patients (26.7\%), 16 women and $19 \mathrm{men}$, were HPV DNA positive according to the PCR analysis, whereas condylomatas were observed clinically only in 18 patients $(13.7 \%)$. Ten out of 65 men had exophytic warts. Only 7 of these, however were HPV DNA positive.

Twelve male patients had acetowhite lesions suspicious of HPV infection, and five of them were PCR positive. Of the seven with suspicious lesions but without detectable HPV DNA, five had urethritis, that is an inflammatory condition in the mucous membranes that could have explained the acetowhiteness.

Thirteen men had a past history of condylomata acuminata (table 1). Five were HPV DNA positive of whom one had a normal examination and four had suspicious lesions. Eight were HPV DNA negative, four with a normal examination, two had current condylomatas and two had suspicious lesions.

Eight out of 66 women had apparent warts, and in six of these women the warts were HPV DNA positive. Out of 12 women with suspicious lesions, eight harboured HPV DNA according to the PCR analysis (table 2). HPV DNA was detected in samples from the vulva and/or cervix in seven patients and only in samples from the outer epithelium in nine patients.

Ten women had a history of condylomata acuminata. Two of these were positive for HPV DNA, one with normal examination and one with suspicious lesions. Out of the eight HPV negative women six showed a normal examination and two had suspicious lesions.

Analysis was only made for HPV types $6 / 11,16$ and 18 (table 3), because of lack of sampling material. These numbers were 
Table 2 Colposcopic findings

\begin{tabular}{|c|c|c|c|c|}
\hline \multirow[b]{2}{*}{ Lesion } & \multicolumn{2}{|l|}{ Men } & \multicolumn{2}{|l|}{ Women } \\
\hline & $P C R+$ & $P C R-$ & $P C R+$ & $P C R-$ \\
\hline $\begin{array}{l}\text { Exophytic } \\
\text { acuminate } \\
\text { papular } \\
\text { Subclinical/suspicious } \\
\text { Normal examination }\end{array}$ & $\begin{array}{l}4 \\
3 \\
5 \\
7\end{array}$ & $\begin{array}{r}2 \\
1 \\
7 \\
36\end{array}$ & $\begin{array}{l}6 \\
8 \\
2\end{array}$ & $\frac{2}{4}$ \\
\hline
\end{tabular}

Table 3 HPV DNA hybridisation results (\%)

\begin{tabular}{|c|c|c|c|c|}
\hline HPV type & $\begin{array}{l}P C R \\
(n=131)\end{array}$ & $\begin{array}{l}\text { Typical } \\
\text { (exophytic) } \\
\text { lesions }\end{array}$ & $\begin{array}{l}\text { Suspiscious } \\
\text { lesions }\end{array}$ & $\begin{array}{l}\text { Normal } \\
\text { epithelium }\end{array}$ \\
\hline $\begin{array}{l}6 / 11 \\
16 \\
18 \\
\text { Untyped numbers* } \\
\text { Coexistence of more than one HPV type } \\
\text { Total positive }\end{array}$ & $\begin{aligned} 10 & (7 \cdot 6) \\
3 & (2 \cdot 3) \\
3 & (2 \cdot 3) \\
21 & (8 \cdot 3) \\
2 & \\
35 & (27)\end{aligned}$ & $\begin{array}{l}8 \\
1 \\
0 \\
4\end{array}$ & $\begin{array}{l}1 \\
2 \\
2 \\
8\end{array}$ & $\begin{array}{l}1 \\
0 \\
1 \\
9\end{array}$ \\
\hline
\end{tabular}

^Hybridisation only performed for HPV 6/11, 16 and 18.

Table 4 Demographic and clinical data of the sample population and the study population

\begin{tabular}{lcc}
\hline Characteristics & $\begin{array}{l}\text { Sample population } \\
\text { number }\end{array}$ & $\begin{array}{l}\text { Study population } \\
\text { number }\end{array}$ \\
\hline Sex & $66(50 \cdot 4 \%)$ & $2,134(46 \cdot 6 \%)$ \\
$\quad$ Female & $65(49 \cdot 6 \%)$ & $2,445(53 \cdot 4 \%)$ \\
Male & & \\
Age (yr) & & \\
Female & $17-47$ & $15-61$ \\
$\quad$ Range & 24 & 24 \\
$\quad$ Median & $20-53$ & $15-79$ \\
Male & 25 & 25 \\
$\quad$ Range & & \\
$\quad$ Median & $18(13 \cdot 7 \%)$ & $576(12 \cdot 6 \%)$ \\
Prevalence & $3(2 \cdot 3 \%)$ & $136(2 \cdot 9 \%)$ \\
Ano-genital warts (diagnosed by inspection) & $6(4 \cdot 6 \%)$ & $244(5 \cdot 3 \%)$ \\
Genital herpes & $25(19 \cdot 1 \%)$ & $926(20 \cdot 2 \%)$ \\
Chlamydial infection & $10(7 \cdot 6 \%)$ & $239(5 \cdot 2 \%)$ \\
Non specific urethritis & $9(6 \cdot 9 \%)$ & $344(7 \cdot 5 \%)$ \\
Bacterial vaginosis & 131 & \\
Candidiasis & & 4,579 \\
Total & & \\
\hline
\end{tabular}

^Non-gonococcal-non-chlamydial infection.

chosen because they represent "low-risk" and "high-risk" HPV types concerning oncogenic potential. HPV $6 / 11$ was found in 10 patients, of whom eight had exophytic warts. HPV 16 and 18 were mostly found in the group with suspicious or subclinical lesions. The percentages of other STDs in the sample studied were comparable to those among all patients attending during the year of the study (table 4).

The total lack of gonorrhoea in this material is in accordance with the situation in Sweden today. The few cases seen are due to sexual contacts from abroad and are usually found by direct microscopy, that is examination of urethral smears, which is done in all patients.

HIV testing was offered to all and accepted by 63 , all screened negative with the ELISA technique.

\section{Discussion}

Among randomly selected first-time visitors seen in a Swedish STD clinic, 30.5\% showed signs of HPV infection, either clinically and/or as HPV DNA positivity on PCR analysis. Thus it is obvious that HPV infections are much more common than has been estimated after conventional examination of the patients.

HPV of uncertain type was identified in 21 patients and appeared more common than HPV 6/11, 16 and 18 in suspicious lesions and in patients with a normal examination. We had no possibility of checking for more than three HPV types owing to lack of sampling material. Probably the uncertain HPV types represents both HPV 31, 33, and 35 and the so called HPV $\chi^{11}$ which are known to be harboured in suspicious lesions. ${ }^{12}$

It is worthy of note that three of the ten male patients with condyloma acuminatum were PCR negative. Two of these three men had had warts for four years or more. It is known that the longer the infection has lasted, the less virus is present. ${ }^{13}$ The third patient had the lesions on the penile shaft. Detection of virus in such a location may be more difficult, since keratinizing squamous epithelium does not exfoliate cells easily. Moreover, anucleate squames are mostly obtained. For virus detection the nuclear content is required. ${ }^{14}$

One of the women, aged 30 years, had had warts diagnosed in 1976. She obviously had a latent HPV infection, since although there were no clinical signs or symptoms of infection, HPV 18 was present. This is consistent with the report that "high-risk" HPV can usually be traced for longer periods in the epithelium than the "low-risk" types. ${ }^{15}$ Reinfection can not be excluded, however. This and our finding that seven out of thirteen male patients without signs or symptoms of current disease but with a previous history of HPV infection either were HPV DNA positive (five patients) or had subclinical lesions (two patients) suggestive that they are infectious, is from an epidemiological point of view important.

The findings that approximately one-third of the patients at an STD clinic are carriers of HPV DNA is most notable in view of the fact that we consider our figures minimal. The negative PCR result in some of the patients with clinically apparent warts might have been false negative. Such a phenomenon is not an uncommon finding when culturing for other STDs such as chlamydia infection. The lower detection rate of chlamydia in men compared with women has been attributed to the anatomical difference, with easier collection of cells in women. Such a discrepancy was not noted in this study concerning HPV DNA detection.

We did not find any association between HPV DNA positivity and the presence of papillomatosis. There were two women with this condition in the PCR-positive group and six in the PCR-negative. The aetiology of papillomatosis and hypertrophic mucosa that are sometimes seen on the penis and more commonly in the vulvar region is still under debate. Some studies indicate an association, whereas others do not. ${ }^{316}$ There was a more obvious relationship between acetowhite 
patches and HPV DNA positivity. However, in one study it was shown that acetowhite mucosal changes comprise a spectrum of histological abnormalities including such conditions as unspecific inflammation and different dermatoses. ${ }^{17}$

Further studies are needed to assess the value of the acetic acid test and to investigate the aetiology both of the whitening of the epithelium and the hyperplasia of the penis and vulva that is termed papillomatosis. The study on this issue mentioned above ${ }^{17}$ was made on men, and additional investigations in women are required.

1 Wikström A, Lidbrink P, Johansson B, von Krogh G. Penile human papillomavirus carriage among men 1991:2:105-9.

2 van Doornum GJ, Hooykaas C, Juffermans LHJ. Prevalence of human papillomavirus infection among heterosexual men and women with multiple sexual partners. F Med Virol 1992;37:13-21.

3 Bodén E, Rylander E, Evander M, Wadell G, von Schultz B. Papillomavirus infection of the vulva. Acta Obstet Gynecol Scand 1989;68:178-84.

4 Gayle HD, Keeling RP. Prevalence of the human immunodeficiency virus among university students. $N$ Engl ₹ Med 1990;323:1538-41.

5 Sexual behavior among high school students-United States, 1990. MMWR 1992;40:885-8.

6 Evander M, Wadell G. A general primer pair for amplification and detection of genital human papillomavirus types. 7 Virol Method 1991;31:239-50.

7 Manos MM, Ting Y, Wright DK, Leweis AJ, Broker TR, Wolinksy SM. Use of polymerase chain reaction amplification for the detection of genital human papillomavirus. Cancer Cells 1989;7:209-14.

8 Snijders PJF, van den Brule AJF, Schrijnemakers HJF, Snow G, Meijer CJLM, Walboomers JMM. The use of general primers in the polymerase chain reaction permits the detection of a broad spectrum of human papillomavirus genotypes. f Gen Virol 1990;71:173-81.

9 Saiki RK, Scarf S, Faloona F, et al. Enzymatic amplification of $\beta$-globin genomic sequences and restriction site tion of $\beta$-globin genomic sequences and restriction site 230: $1350-4$

10 Evander M, Edlund K, Bodén E, et al. Comparing a onestep and a two-steppolymerase chain reaction with degenerate general primers in a population-based study of human papillomavirus infection in young swedish women. F Clin Microbiol 1992;30:987-92.

11 Melkert PWJ, Hopman E, van den Brule AJC, et al. Prevalence of HPV in cytomorphologically normal smears, as determined by the polymerase chain reaction, is age-dependent. Int 7 Cancer 1993;53:919-23.

12 Löwhagen G-B, Bolmstedt A, Ryd W, Voog E. The prevalence of "high-risk" HPV types in penile condyprevalence of "high-risk" HPV types in penile condy-
loma-like lesions: correlation between HPV type and loma-like lesions: correlation between HPV

13 Oriel JD, Almeida JD. Demonstration of virus particles in human genital warts. Br $\mathcal{F}$ Veneral Dis 1970;46:37-42.

14 Krebs HB, Schneider V. Human papillomavirusassociated lesions of the penis: colposcopy, cytology and histology. Obst Gynecol 1987;70:299-304.

15 Schiffman $\mathrm{MH}$. 11th international papillomavirus workshop 1992. Papillomavirus Rep 1992;3:164-7.

16 Bergeron C, Ferenczy A, Richart RM, Gueralnick M. Micropapillomatosis labialis appears unrelated to human papillomatosis. Obst Gynecol 1990; 76:281-6.

17 Wikström A, Hedblad M-A, Johansson B, et al. The acetic acid test in evaluation of subclinical genital papillomavirus infection: a comparative study on penopscopy, mavirus infection: a comparative study on penopscopy,
histology, virology and scanning electron microscopy findings. Genitourin Med 1992;68:90-9. 